Tonkonoh Irina,

Senior tutor, $\mathrm{PhD}$ (Pedagogics), Kyiv National University of Trade and Economics, 19, Kyoto str., Kyiv, 02156, Ukraine

ORCID: 0000-0001-8488-8526

Researcher ID: O-4246-2016

Pryma Viktoriia,

Assistant Professor, PhD (Germanic Languages), Kyiv National University of Trade and Economics, 19, Kyoto str., Kyiv, 02156, Ukraine ORCID: 0000-0001-7331-9950,

Researcher ID: N-1582-2016 Yuvkovetska Yuliia, Assistant Professor, PhD (Philosophy), Kyiv National University of Trade and Economics, 19, Kyoto str., Kyiv, 02156, Ukraine ORCID: 0000-0001-9212-6943

Researcher ID: https://publons.com/researcher/1688159//

\title{
CRITERIA, INDICATORS AND LEVELS OF COMMUNICATIVE COMPETENCE OF RESTAURANT AND HOTEL BUSINESS FUTURE SPECIALISTS
}

The subject of authors' study of the article is the definition and characteristics of components, criteria and indicators of communicative competence among students of economic universities, future specialists in the field of hospitality. Different points of view of scholars on the definition of the concepts of «competence» and «communicative competence» in higher education are presented. Requirements for the communicative competence of restaurant and hotel business specialists are presented.

The structure of communicative competence of future specialists in the field of hospitality, which consists of the following components: value-motivational, contentoperational, value-reflexive. During the investigation, it was found out that criteria and indicators of the expression of the indicated components are subject-oriented (motivation for achievement of high results in communication, goal-setting (purposefulness, comprehension of the value relation to communication in future professional activities)).

Information-practical (ability to establish contacts, understand the inner world of another person, ability to cooperate, achieve compromises, communicative 
flexibility); operational-behavioural (the formation of a positive "I-concept», the ability to understand and comprehend their own actions during communication). In addition, according to the defined criteria and indicators, the level of communicative competence of the future specialist in the sphere of hotel and restaurant business is defined: reproductive, technological, and creative.

Key words: communicative competence, structure, criteria, indicators and levels of communicative competence.

\section{Тонконог Ірина, Прима Вікторія, Ювковецька Юлія. Критерії, показники} та рівні компетентності майбутніх спеціалістів в сфері ресторанно-готельного бізнесу.

Предмет дослідження автора статті - визначення та характеристика компонентів, критеріїв та показників комунікативної компетентності у студентів економічного ВНЗ, майбутніх спеціалістів у сфері гостинності. Представлено різні точки зору науковиів на дефініції понять «компетентність» та «комунікативна компетентність» у вищій школі. Наведено вимоги до комунікативної компетентності спеціалістів ресторанно-готельного бізнесу. Подано структуру комунікативної компетентності майбутніх фахівиів в сфері гостинності, яка складається з таких компонентів: иіннісно-мотивачійний, змістово-операційний, ціннісно-рефлексивний. Під час дослідження з'ясовано, що критеріями і показниками вияву означених компонентів є суб' єктно орієнтований (мотиви на досягнення високих результатів в спілкуванні, иілепокладання (цілеспрямованість, осмислення ціннісного ставлення до спілкування у майбутній професійній діяльності)); інформаційно-практичний (здатність встановлювати контакти, розуміти внутрішній світ іншої людини, здатність до співпращі, досягнення компромісів, комунікативна гнучкість); операційно-поведінковий (сформованість позитивної «Я-конщепції», вміння усвідомлювати і осмислювати власні дії під час спілкування). Окрім того згідно з означеними критеріями і показниками визначено рівні комунікативної компетентності майбутнього фахівия в сфері готельно-ресторанного бізнесу: репродуктивний, технологічний, творчий.

Ключові слова: комунікативна компетентність, майбутніх фахівиі в сфері ресторанно-готельного бізнесу, сфера гостинності, структура комунікативної компетентності,критерії, показники та рівні комунікативної компетентності.

Relevance of research topic. Trends in economy globalization, the entry of Ukraine into the international educational space need to address the quality problems of vocational training of graduates of vocational education institutions, the development of readiness for effective functioning in developing countries in socioeconomic conditions in the labour market.

An important task in the area of professional education today is the creation of mechanisms that ensure the quality of educational services from the standpoint of the 
requirements of professional activity - the preparation of a competitive specialist with a complex of competencies which meet the requirements of the modern labour market.

One of the sectors of the economy, which is developing dynamically today, is the food and hospitality industry, which has a shortage of professionally trained staff of restaurateurs, hoteliers, and restaurant and hotel business managers. Hotel and restaurant complexes, created in the country, require a constantly growing number of skilled workers with a high level of professional competence, able to work effectively in a specialty at the international standards level.

As Zarembi research shows, the average annual rate of growth of the restaurant business in Ukraine today is $121.5 \%$, which is due to the attractiveness of investing in this business. As in recent years, our country has become the focal point of many different international forums, has become interested in tourism, recreation and treatment, then demand and demands on the structure and quality of restaurant services of our country's citizens have changed, which seeks not only to receive quality food from restaurants, but also to feel the comfort, the culture of service, aesthetic pleasure, understanding of own preferences (Primuk, 2016).

The training of highly skilled personnel can be achieved on the basis of a competent approach in vocational education, which allows the graduate of an economic educational institution to successfully apply the acquired knowledge, skills, skills to solve practical production tasks, to effectively conduct business communications, to be prepared for life-long learning because of changes in the requirements of professional activity.

A specialist in the field of service should be not only professional, but also well know the principles of communication have a thorough knowledge of various types of speech activity, be able to skillfully negotiate with clients. Especially it is necessary to highlight communicative qualities, precisely, communicative competence that provides an effective interaction with people.

The formation of communicative competence is a topical problem, the solution of which is important both for each individual person and for society as a whole. Person carries out both his professional and personal plans in the field of communication, moreover the specialist of the hospitality sphere.

An expert in the field of restaurant and hotel business must be a philologist, regardless of the clients' communicate level, where the most important working tool is his word. To the specialists of the sphere of service the society demands high requirements, including dialogical openness and ability to be a communicative leader.

It is these skills that adapt to more successful socialization in the professional field. This is holding of rhetoric service, which results in client's reaction that allows you to build a trajectory and tactics of future long-term cooperation, as well as outline, possible network marketing for the promotion and implementation of a service or product. 
Purposeful systematic formation of future specialists in speech competence services is one of the ways of solving this problem as a factor of successful professional socialization.

The education of such specialists is possible only with a radical rethinking of the ultimate goals of professional training in the direction of forming incoherent knowledge, skills and abilities, and an integrated set of basic and professional-oriented competences of specialists, among which the important role is played by the communication competence of hotel and restaurant business personnel.

Formation of the problem. The concept of the development of economic education in Ukraine emphasizes on the importance of the content of vocational and economic education, which is determined by the requirements for its final result - the formation of a harmonious, many-sided person, for which professional knowledge, skills, and skills and their constant updating form the basis of self-realization in the economic sphere of society (Dragunova, 2005).

Analysis of recent researches and publications. The analysis of scientific methodological and special pedagogical literature gives reasons to claim that the issues of preparation of future specialists for the hotel-restaurant industry is substantiated in the works of such specialists as V. Lozovetska, N. Nichkalo, V. Oobozny, M. Skrypnyk, G. Tsekhmistrova, V. Fedorchenko and others. Theoretical and methodological approaches of structure grounding and principles of forming of tourist's education forming are described in works of such researches as: Ye. Aliluyko, I. Zorina, M. Kabushkina, V. Kvartalnova, V. Oobozny, V. Fedorchenko. Communicative competence of personality was studied by a number of researchers; V. Hazaeva (Gvazava，2011)，O. Zhuravleva， N. Kozelova (Kozelova 2010)， N. Komohorova (Kolmogorova, (2004), O. Muravyova (Muraveva, 2012), Ye. Mutachvili (Mutachvili, 2016), and others.

Analysis of research and experience of practical training of hotel and restaurant business experts has allowed distinguishing between:

- modern requirements of the labour market of specialists in the sphere of hospitality and service and the limited possibilities of their satisfaction with the modern system of professional education;

- the necessity to improve the quality of professional education of service professionals and the lack of development of methodology, theory and technology of its achievement - the needs of individual in intellectual, cultural and professional development, ensuring its competitiveness in the labour market and the limited ability to meet them under the conditions of higher education.

The revealed contradictions allowed formulating the research problem: the substantiation of the criteria and levels of communicative competence of future specialists in the sphere of hotel and restaurant business in the conditions of higher educational establishments. 
The purpose of the article is to determine the criteria, indicators, levels of the formation of communicative competence of future professionals in the field of hospitality.

Presenting main material. In the scientific context, the combination of terms «communicative competence» was firstly used in social psychology (from Lat. competens - «capable») and was interpreted as the ability to establish and maintain effective contacts with other people in the presence of internal resources (knowledge and skills). In the explanatory dictionary, by S. Ozhegov, the notion of «competence» as an independent semantic linguistic unit is used more often in the sense of «level of knowledge of a certain branch of knowledge» or «knowledge and experience in a particular industry» (Ozhegov, Shvedova, 1999).

The term «competence» receives a broad scope and functions in a semantic space, where there is no obvious distinction between the concept of «competence» and concepts such as «competence», «qualification», "professional preparedness», «knowledge, skills, and abilities» (G. Kolshansky, S. Kulnevich, S. Kucher, O. Lebedev, L. Cherepanov and others). In this case, the concept of «competence» in some sources is defined as a given norm, and «competence» - as the personal qualities (set of qualities) of the subject in relation to any of its activities, as a certain characteristic of the person, which is guided by the topic.

In the analysis of the approaches to the concept of «competence», we will adhere to the definition, which was substantiated by M. Kholodna: «Competence is a special type of organization of subject-specific knowledge, which allows making effective decisions in the relevant field of activity» (Kholdnaya, 2002).

The authors of the psychological dictionary A. Petrovsky, M. Yaroshevsky determine the essence of the concept of «communication» in the sense, first of all, the communication of people and their generalization of knowledge (Psyhologichesky slovar, 1990).

Despite a significant number of pedagogical studies (A. Markova, V. Slastonin, etc.) and psychological (E. Zeer, E. Klimov, N. Kuzmin, L. Mitina, E. Rogov, A. Fonarev, etc.) of research in the humanities there is no clear understanding as well as generally accepted interpretation of the very concept of «communicative competence,» including a specialist in the sphere of hospitality. There is no complete picture of its structure and content.

Some scholars understand the communicative competence of knowledge, skills and abilities that allow you to understand someone's speech behaviour and reproduce your own in the light of the situation, goals, conditions of communication, as well as the speaker's experience (R. Bell). Others, in the communicative competence, see two competencies that are related to the processes of creation (competence of production) and speech reception processes (competence of perception) (M. Vyatyutnev (Vyatyutnev, 1984)). 
The notion of «communicative competence» is determined differently by different researchers:

- As a system of internal resources that are necessary for building an effective communicative action in a certain range of situations of interpersonal interaction (Petrovskaya, 1989);

- this level of interpersonal experience, that is, the training of interacting with others that is required by the individual, so that within the framework of abilities and social status to operate successfully in a given society (Borozdina, 2002);

- as a system of internal resources of an individual that is necessary for it to carry out effective communicative actions in a wide range of situations of interpersonal interaction (Rudensky, 1999);

- the ability to solve effectively communication problems, which determines the individual psychological characteristics of the individual and ensures the effectiveness of its communication and interaction with other people (Emelyanov, 1995);

- the ability to communicate effectively and to develop communicative skills (Leont'yev, 1975);

- how to possess complex communicative skills and abilities, knowledge of cultural norms and restrictions in communication, knowledge of customs, traditions, etiquette in the field of communication, adherence to rules of decency, politeness (Kunitsyna, Kazarinova, Pogol'sha, 2001).

Conclusion. Despite the different interpretations of the concept of communicative competence by scholars, all authors believe that this phenomenon is associated with the ability to establish and maintain the necessary contacts with other people.

From our point of view, «communicative competence» is a holistic, integrative, multicomponental mental entity that determines the effectiveness of communication. It is established that the structure of communicative competence of future specialists in the field of hospitality consists of the following components: value-motivational, content-operational, value-reflexive, criteria and indicators of the expression of the indicated components is subject-oriented (motives for achieving high results in communication, goal-setting (purposefulness, comprehension complete communication in relation to future professional activity)); information-practical (ability to establish contacts, understand the inner world of another, ability to cooperate, achievement of compromises, communicative flexibility); operational-behavioural (the formation of a positive «I-concept», the ability to understand and reflect on my own actions).

According to the mentioned criteria and indicators, the levels of communicative competence of the future specialist in the sphere of hotel and restaurant business are defined: reproductive, technological, creative. 


\section{REFERENCES}

1. Alifanova Ye. M. (2001) Formirovaniye kommunikativnoy kompetentsii detey doshkol'nogo imladshegoshkol'nogo vozrasta sredstvami teatralizovannykh igr: [The Formation of communication competence of pre- and junior schoolchildren by theatrical games] Unpublishedcandidatedissertation, Volgograd, Russia.

2. Bell R. T. (1980) Sotsiolingvistika: Tseli, metody, problemy [Sociolinguistics: Aims, methods, problems] / pod red. A. D. Shveytsera. - M.: Mezhdunarodnyye otnosheniya.

3. Bodalev A. A. (1988) Psikhologiya lichnosti [Psychology of individual]. M.: Izd-vo MGU.

4. Borozdina G. V. (2002) Psikhologiya delovogo obshcheniya [Psychology of busines communication] / G.V. Borozdina. - M.: INFRA-M.

5. Vyatyutnev M. N. (1984) Teoriya uchebnika russkogo yazika kak inostrannogo [Theory of Russian textbook as the foreign] / M. N. Vyatyutnev. - M.: Russkiyyazyk.

6. GvazavaV. I. (2011) Kommunikativnaya kompetentnost' spetsialista servisa [Communicative competence of service specialists] / V. I. Gvazava // Zapiski Gornogo instituta.

7. Dragunova T. A. (2005) Formuvaniatrudovykh resources in the resort and recreation area and tourist sphere [Formation of labour resources of recreation and tourist sphere] / T. A. Dragunova, I. P. Majdanik, L A. Chvertko // Regional problems and development of tourism and recreation: zb. sciences. prat; NAS of Ukraine. Donetsk: Southeast, Ltd.

8. Emelyanov Yu. N. (1995) Teoriya formuvanniai praktika sovershenstvovaniya komunikativnoy kompetentnosti [Theory of Formation and the Practice of Improving Communicative Competence] / Yu. N. Emelyanov. - M.: Enlightenment.

9. Zhukov Yu. M., Petrovskaya L. A., Rastyannikov P. V. Diagnostika I Razviriye (1990) Kompetentnosti v Razvitii [Diagnostics and development of competence in communication]. - M.: Publishing House of Moscow. Un-ta.

10. Kazakov A. V. (2012) Organizatsiya Protsesa Formuvannya Sociokulturnoyi Kompetentsii spetsialistiv sfery obslugovuvannia $\mathrm{v}$ suchasnyh umovah [Organization of the process of formation of sociocultural competence of service professionals in modern conditions / A. V. Kazakov // Kazan science.

11. Klyuyeva Ye. V. (2007) Rechevaya kommunikatsiya. Neverbal'nyye komponenty kommunikatsii. [Verbal communication. Non-verbal components of communication] LKI.

12. Kozelova N. A. (2010) Kriterii, pokazateli, urovni sformirovannosti kommunikativnoy kompetentnosti studentov agroinzhenernogo vuza [Criteria, indicators, levels of students' communicative competence // Lichnost', sem'ya i obshchestvo: voprosy pedagogiki i psikhologii: sb. st. po mater. II mezhdunar. nauch.prakt. konf. - № 2. - Chast’ II. - Novosibirsk: SibAK. 
13. Kolmogorova N. S. (2004) Kommunikativnaya kompetentnost' kak usloviye isledstviye stanovleniya napravlennosti lichnosti: [Communicative competence as condition and consequence of individual development] Unpublished candidate dissertation - Barnaul.

14. Kunitsyna V. N., Kazarinova N. V., Pogol'sha V. M. (2001) Mezhlichnostnoye obshcheniye: [Individual Communication] - SPb.: Piter.

15. Leont'yev A. A. (1975) Obshcheniye kak ob'yekt psikhologicheskogo issledovaniya [Communication as an object of psychological investigation]. - M.: Nauka.

16. Lomov B. F. (1984) Metodologicheskiye i teoreticheskiye problem psikhologii [Methodological and Theoretical Problems of Psychology]. - M.: Nauka.

17. Mitina L. M. (2004) Komunicativnye aspekty kompetentnosti [Communicative aspects of competence]. - M.: Academy.

18. Mudrik A. V. (2001) Obshcheniye v protsese vospitaniya [Communication in the process of education]. - M.: Pedagogical Society of Russia.

19. Muraveva O. I. (2012) Psichologiya komunikativnoy kompetentnosti [Psychology of communicative competence]. - Tomsk: Because of Tom. University.

20. Mutavchi E. P., Samsonova N. V. (2016) Komunikativno-servisnaya kompetentnost' spetsialistov sfery gostepriimstva [Communicative service competence of hospitality professionals] // World of Science, Culture, Education.

21. Ozhegov S. I., Shvedova N. Yu. (1999) Tolkovy slovar' russkogo yazka. [Explanatory dictionary of the Russian language. 80000 words and phraseological expressions]. - M.: Azbukovnik.

22. Petrovskaya L. A. (1989) Kompetentnost' v obshchnii [Competence in communication] / L. A. Petrovskaya. - M.: Publishing House of Moscow State University.

23. Petrushin S. V. (1995) Sotsialno-psyhologicheskiy trening v mnogochislennoy gruppe kak sredstvo razvitiya kompetentnosti $\mathrm{v}$ obshchenii: [Socio-psychological training in a large group as a means of developing competence in communication]: Unpublished candidate dissertation. - Kazan.

24. Primuk O. O. (2016) Osobnivosti form of professionally important importance of maybutnih fahivtsiv restaurant biznesu [Peculiarities of forming of professional important qualities of future specialists of restaurant business] // Zbirnik naukovih prats k-PNU imeni Ivana Oginka, Institute of Psychology imeni G. S. Kostyuka NAPS Ukraine. - Problems with modern psychology.

25. Psyhologicheskyslovar. (1990) [Psychological dictionary] / Under total. ed. A. V. Petrovsky, M. G. Yaroshevsky. $-2^{\text {nd }}$ ed., Corr. and add. - M.: Politizdat.

26. Rogov Ye. I. (2005) Psychologiya obshcheniya. [Psychology of communication]. - M.: Humanitarian. Center VLADOS.

27. Rudensky, Ye. V. (1999) Sotsialna psyhologiya. [Social psychology: A course of lectures]. - M.: Infra-M; Novosibirsk: NGAEiU.

28. Kholdnaya M. A. (2002) Psikhologiya intelekta. [The psychology of intelligence. Paradoxes of research]. - SPb.: Peter. 